\title{
Mechanical Properties of Thermally Modified Corymbia Citriodora and Eucalyptus Saligna Woods
}

\author{
Walmir Marques de Menezes ${ }^{1}$ (D), Joel Telles de Souza ${ }^{1}$ (D), \\ Douglas Edson Carvalho ${ }^{2}$ (D), Maiara Talgatti ${ }^{1}$ (D), Elio José Santini ${ }^{1}$
}

${ }^{1}$ Departamento de Ciências Florestais, Universidade Federal de Santa Maria - UFSM, Santa Maria/RS, Brasil ${ }^{2}$ Departamento de Ciências Florestais, Universidade Federal do Paraná - UFPR, Curitiba/PR, Brasil

\begin{abstract}
This study aimed at evaluating thermal modification in mechanical properties of Corymbia citriodora and Eucalyptus saligna woods compared with a control. To do so, three samples of each species were selected, with approximately 40 years, which had the first two three-meter long logs removed. Wood thermal modification was done through final temperatures of $140{ }^{\circ} \mathrm{C}$, $160^{\circ} \mathrm{C} \mathrm{e} 180^{\circ} \mathrm{C}$ for 2.5 hours, and the control as well, using a forced air circulation greenhouse. Mechanical properties tests consisted of maximum impact resistance evaluation, static bending, and fiber parallel compression. Generally, results showed that thermal modification increases wood resistance up to a certain point and reduces in the highest temperature.
\end{abstract}

Keywords: final temperatures, maximum impact resistance, static bending, fiber parallel compression. 


\section{INTRODUCTION}

The search for solutions that aim at adding more value to planted forests is increasing. Following this perspective, thermorretification, which is a thermal treatment that intends to give wood greater superficial hardness, higher antifungal potential, a better appearance, and mechanical and physical characteristics, besides providing it with higher dimensional stability (Moura et al., 2012), arises as a nurturing source of such demand.

High temperatures, but lower than the carbonization point, $\sim 280^{\circ} \mathrm{C}$, (Figueroa \& Moraes, 2009), applied to wood during the thermorretification process may cause resistance loss three times higher when compared to the original. These losses are triggered by excessive heat that occurs because of two different effects: the immediate and reversible, which happens only during the period in which the temperature is kept; and the permanent, which results from cell wall polymers thermal degradation (Stamm, 1964; Winandy \& Rowell, 1984).

Araújo et al. (2012) state that, when they undergo thermal treatment, wood can normally be used for coatings, soundproof walls, floorings, terraces, ship decks, garden furniture, door and window jambs, children's playground, indoor and outdoor furniture, gates, fences, musical instruments and so on.

Generally, thermal treatments cause chemical, physical and mechanical changes in wood (Rodrigues, 2009). However, when mechanical properties are assessed after applying high temperatures, either increases or decreases are perceived in the values of these properties, which generates contradictions. Some divergences lead to believe that these changes vary among different woods and depend on parameters used in thermal treatments such as time of heat exposure.

In such context, this study aimed at evaluating the effect of thermal treatment of mechanical properties of Corymbia citriodora and Eucalyptus saligna woods, through static bending (MOE and MOR), dynamic bending (maximum impact resistance) and fiber parallel compression.

\section{MATERIAL AND METHODS}

The species used in this study were Corymbia citriodora (Hook.) K.D. Hill \& L.A.S. Johnson and Eucalyptus saligna Sm, collected in plantation of the
Agricultural Research State Foundation - Fepargo Forests, located in Santa Maria, RS.

From each species, three trees with approximately 40 years were selected. The trees had had their first two logs sliced with $3.0 \mathrm{~m}$ of length, $10 \mathrm{~cm}$ above the ground in order to manufacture boards with approximate dimensions of $2.5 \mathrm{~cm}$ of thickness, $15.0 \mathrm{~cm}$ of width, and $280 \mathrm{~cm}$ of length, through the tangential unfolding method, using the central transom of each log with $8 \mathrm{~cm}$ of thickness. Then, the boards were transferred to the Laboratory of Forest Products (LFP) of the Federal University of Santa Maria, where the material to carry out the study was prepared.

Before thermal modification treatment, the boards underwent previous drying until a $10 \%$ moisture level in a pilot greenhouse with nominal capacity for $1 \mathrm{~m}^{3}$ of lumber. A drying program with initial temperature of $39^{\circ} \mathrm{C}$ and $40^{\circ} \mathrm{C}$, final temperature of $68^{\circ} \mathrm{Ce} 67^{\circ} \mathrm{C}$, and drying potential (wood moisture/equilibrium moisture relation) of 2.1 for C. citriodora and E. saligna woods, respectively, was used.

For the execution of thermal modification treatment, a forced convection and digital controlled temperature electric greenhouse was used. For treatment conduction, 400 specimens with dimensions of $2.0 \mathrm{~cm}$ of thickness, $2.0 \mathrm{~cm}$ width, and $32 \mathrm{~cm}$ length underwent final temperatures of $140{ }^{\circ} \mathrm{C}, 160{ }^{\circ} \mathrm{C}$ e $180^{\circ} \mathrm{C}$ during 2.5 hours. The atmosphere of treatments is natural, containing higher levels of oxygen and warming rates of $0.93,1.06 \mathrm{e} 1.12^{\circ} \mathrm{C} / \mathrm{min}$ for each temperature used. Previously to the treatment, using the methodology proposed by Calonego (2009), the wood underwent initial temperature of $100{ }^{\circ} \mathrm{C}$ for 14 hours in order to reduce humidity level near $3 \%$, trying to avoid possible water steam expansion and cell wall rupture. Then, specimens were resized according to each test for treatment. Mechanical properties tests were carried out following the procedures set by the rule ASTM (2000) and adaptations (ASTM 143-94). In addition, maximum impact resistance test followed the rule NBR (rule) 7190 (ABNT, 1997), using the Charpy Pendulum, with capacity for 100 joules. To this test, 160 specimens were manufactured, of which 20 (10 radial and 10 tangential) for each treatment, with dimensions of $2 \times 2 \times 30 \mathrm{~cm}$ (radial, tangential and longitudinal).

In static bending tests, the universal mechanical testing machine was used. For each species, 240 specimens 
with dimensions of $2 \times 2 \times 32 \mathrm{~cm}$ (radial, tangential and longitudinal) were manufactured. Subsequently, specimens were placed in a $28 \mathrm{~cm}$ gap and a $1.3 \mathrm{~mm} / \mathrm{min}$ controlled speed. In order to assess thermally modified sample properties and the control, the modulus of elasticity (MOE) and rupture (MOR) were determined in static bending.

The fiber parallel compression test was carried out in the universal mechanical testing machine. To do so, 240 specimens with dimensions of $2 \times 2 \times 8 \mathrm{~cm}$ (radial, tangential and longitudinal) were manufactured for each species. A 0.001 sensitive extensometer attached to the wood and to the machine control computer assessed specific deformations. The fiber parallel compression test determined the maximum load supported by the specimens and maximum resistance to axial compression was calculated from such data.

Mechanical properties data were organized and analyzed in Excel $2015^{\circledR}$ software. Data were also statistically processed by the Statgraphics Centurion XV.II software. When substantial differences were detected, the averages were compared through the Tukey test in $5 \%$ probability of error. Treatment effects were assessed with variance analysis.

\section{RESULTS AND DISCUSSION}

Table 1 shows the average values of maximum impact resistance test and the summary of statistical analysis. Either radial or tangential maximum impact resistance averages demonstrated a sharp decrease as temperature rose. The highest decreases in relation to controls were in Eucalyptus saligna, with $76.47 \%$ in radial direction and $73.80 \%$ in tangential direction. The lowest decrease occurred in Corymbia citriodora with $6.77 \%$ in radial direction.

Values near to these were found by Modes (2010), who studied two thermal treatment methods, one in a greenhouse and the other one in a combined way (autoclave + greenhouse). Such methods were applied in a temperature of $160{ }^{\circ} \mathrm{C}$ for three hours to Eucalyptus grandis wood. Thus, the author observed a decrease of $37.75 \%$ in impact resistance values using the greenhouse method and 57.95\% using the combined method when compared to the control. Sundqvist et al. (2006) obtained results within the interval found in this research by applying the treatment of $160{ }^{\circ} \mathrm{C}$ to Betula pubescens wood for 2.5 hours in the presence of steam, where values of $31.03 \%$ lower in relation to the original wood were found.

For Gündüz et al. (2008), depending on the method applied, there can be significant decreases in wood impact resistance. However, some methods do not cause effects over this property or do in minor extensions.

According to Davis \& Thompson (1964), degradation of hemicelluloses is the main reason for wood impact resistance decrease. Following the same authors, cellulose and hemicellulose are based on secondary bonds. Thus, the breakage of such bonds determines impact resistance. Besides these breakages, covalent bond ruptures in cellulose little fibers increase the amount of crystalline cellulose and/or amorphous cellulose crystallization, causing wood tenacity reduction. In corroboration with this, Zanuncio et al. (2014) verified in their studies

Table 1. Maximum impact resistance test averages of Eucalyptus saligna and Corymbia citriodora woods according to treatments and direction of parts.

\begin{tabular}{|c|c|c|c|c|c|c|c|}
\hline \multirow[b]{2}{*}{ Species } & \multirow[b]{2}{*}{ Treatments } & \multicolumn{6}{|c|}{ Maximum impact resistance test } \\
\hline & & $\begin{array}{c}\text { Radial } \\
\left(\mathrm{KJ} / \mathrm{mm}^{2}\right)\end{array}$ & $\begin{array}{c}\text { Decrease } \\
(\%)\end{array}$ & $\begin{array}{c}\text { EMC } \\
(\%)\end{array}$ & $\begin{array}{l}\text { Tangential } \\
\left(\mathrm{KJ} / \mathrm{mm}^{2}\right)\end{array}$ & $\begin{array}{c}\text { Decrease } \\
(\%)\end{array}$ & $\begin{array}{c}\text { EMC } \\
(\%)\end{array}$ \\
\hline \multirow{4}{*}{ Eucalytus saligna } & Control & 85.47 a & -- & $10.72 \mathrm{a}$ & $76.22 \mathrm{a}$ & -- & $10.51 \mathrm{a}$ \\
\hline & $140^{\circ} \mathrm{C}$ & $63.72 \mathrm{~b}$ & 25.45 & $6.85 \mathrm{~b}$ & $34.25 \mathrm{~b}$ & 55.07 & $7.27 \mathrm{~b}$ \\
\hline & $160^{\circ} \mathrm{C}$ & $62.82 \mathrm{~b}$ & 26.50 & $6.26 c$ & $33.29 \mathrm{~b}$ & 56.32 & $5.87 \mathrm{c}$ \\
\hline & $180^{\circ} \mathrm{C}$ & $20.12 c$ & 76.47 & $5.82 \mathrm{~d}$ & $19.97 \mathrm{c}$ & 73.80 & $5.14 \mathrm{~d}$ \\
\hline \multirow{4}{*}{ Corymbia citriodora } & Control & $79.04 \mathrm{a}$ & -- & $10.74 \mathrm{a}$ & $80.67 \mathrm{a}$ & -- & $10.87 \mathrm{a}$ \\
\hline & $140^{\circ} \mathrm{C}$ & $73.69 \mathrm{a}$ & 6.77 & $8.08 \mathrm{~b}$ & $45.63 \mathrm{~b}$ & 43.43 & $8.06 \mathrm{~b}$ \\
\hline & $160^{\circ} \mathrm{C}$ & $33.01 \mathrm{~b}$ & 58.25 & $4.66 \mathrm{c}$ & $31.75 \mathrm{c}$ & 60.64 & $6.34 \mathrm{c}$ \\
\hline & $180^{\circ} \mathrm{C}$ & $28.93 \mathrm{~b}$ & 63.40 & $3.67 \mathrm{~d}$ & $27.80 \mathrm{c}$ & 65.53 & $3.53 \mathrm{~d}$ \\
\hline
\end{tabular}

Note: Averages followed by the same letter for the same species do not differ statistically to the level of $5 \%$ of relevance according to the Tukey test; $\mathrm{EMC}=$ equilibrium moisture content, \%. 
that degradation of hemicelluloses is faster in high temperatures, whereas this process is slower and subtler in lower temperatures, which justifies impact resistance loss in woods that underwent the thermal treatment of highest temperature $\left(180^{\circ} \mathrm{C}\right)$ in the present study.

The values assessed in the average modulus of rupture (MOR) and average modulus of elasticity (MOE), which indicate resistance and rigidity of samples in the static bending test, showed a rigidity significant gain concerning temperatures of 140 e $160^{\circ} \mathrm{C}$ and rigidity loss in the most severe treatment $\left(180^{\circ} \mathrm{C}\right)$.

Modulus of rupture and modulus of elasticity average values for the static bending test of Eucalyptus saligna and Corymbia citriodora woods according to treatments, and interactions between treatments as well, are summarized in Table 2. Table 2 shows that the modulus of elasticity of Eucalyptus saligna had an increase of $3.3 \%$ and $4.8 \%$ in the treatments of $140{ }^{\circ} \mathrm{C}$ and $160^{\circ} \mathrm{C}$ in relation to the control. Still concerning this same species, control treatments, $140{ }^{\circ} \mathrm{C}$ and $160{ }^{\circ} \mathrm{C}$ did not differ statistically to the level of $5 \%$ of probability.

On the other hand, the increase in modulus of elasticity occurred only in the temperature of $140{ }^{\circ} \mathrm{C}$ with $3.2 \%$ in relation to the control for Corymbia citriodora. Decreases in modulus of elasticity occurred in treatments of higher temperatures, $180^{\circ} \mathrm{C}$ with $14.3 \%$ of decrease in relation to control for Eucalyptus saligna, $160^{\circ} \mathrm{C}$ and $180^{\circ} \mathrm{C}$ with decreases of $8.9 \%$ and $14.87 \%$ for Corymbia citriodora in relation to control. Concerning equilibrium moisture level, values were substantially different among each other, denoting that temperature increase reduces this variable.
Modulus of rupture averages were higher in treatments of $140{ }^{\circ} \mathrm{C}$ for both species analyzed. These averages were statistically equal to control for Eucalyptus saligna and different for Corymbia citriodora. Therefore, these treatments had the highest increases of $2.9 \%$ and $11.4 \%$ in modulus of rupture. The most extensive MOR losses occurred in treatments of $180^{\circ} \mathrm{C}$ in other words. The smallest loss happened in the treatment of $160{ }^{\circ} \mathrm{C}$ for Eucalyptus saligna with only $1.4 \%$. It is worth emphasize that Eucalyptus saligna had little decrease in relation to its control. Between control and $160^{\circ} \mathrm{C}$ treatments, MOR values are statistically equal.

Results for static bending tests are similar to the ones found by Calonego (2009) who, by applying final temperatures varying from $140^{\circ} \mathrm{C}$ to $220^{\circ} \mathrm{C}$ for 2.5 hours in Eucalyptus grandis wood, had 8.4\% $\mathrm{MOE}$ and 52.3\% MOR decreases.

In order to explain the increase in MOE value, Esteves \& Pereira (2004) understand that cellulose crystallinity increase and moisture content decrease may assist the increase in static bending resistance. However, this effect predominates in the beginning of the treatment. After continuity, thermal degradation becomes dominant and then causes a decrease in this variable. Over this issue, Boonstra et al. (2007) explains that the decrease occurs because of temperature increase, mainly due to moisture level changes and hemicellulose structure. Furthermore, according to the same authors, treatment time and temperature increases cause more drastic losses in this polymer. Thus, samples that go through thermal treatment process need less energy to their fracture than untreated samples.

Table 2. Averages of static bending test in Eucalyptus saligna and Corymbia citriodora woods according to treatments.

\begin{tabular}{|c|c|c|c|c|c|c|c|c|}
\hline \multirow[b]{2}{*}{ Species } & \multirow[b]{2}{*}{ Treatments } & \multicolumn{7}{|c|}{ Static bending } \\
\hline & & $\begin{array}{l}\text { MOE } \\
\text { (MPa) }\end{array}$ & $\begin{array}{c}\text { Decrease } \\
(\%)\end{array}$ & $\begin{array}{c}\text { Increase } \\
(\%)\end{array}$ & $\begin{array}{l}\text { MOR } \\
(\mathrm{MPa})\end{array}$ & $\begin{array}{c}\text { Decrease } \\
(\%)\end{array}$ & $\begin{array}{c}\text { Increase } \\
(\%)\end{array}$ & $\begin{array}{c}\text { EMC } \\
(\%)\end{array}$ \\
\hline \multirow{4}{*}{ Eucalytus saligna } & Control & $14.94 \mathrm{a}$ & -- & -- & $123 \mathrm{a}$ & -- & -- & $12.68 \mathrm{a}$ \\
\hline & $140^{\circ} \mathrm{C}$ & $15.43 \mathrm{a}$ & -- & 3.3 & $127 \mathrm{a}$ & -- & 2.9 & $9.56 \mathrm{~b}$ \\
\hline & $160^{\circ} \mathrm{C}$ & $15.66 \mathrm{a}$ & -- & 4.8 & $121 \mathrm{a}$ & 1.4 & -- & $8.79 c$ \\
\hline & $180^{\circ} \mathrm{C}$ & $12.81 \mathrm{~b}$ & 14.3 & & $90 \mathrm{~b}$ & 26.6 & -- & $8.09 \mathrm{~d}$ \\
\hline \multirow{4}{*}{ Corymbia citriodora } & Control & $20.41 \mathrm{a}$ & -- & -- & $167 \mathrm{a}$ & -- & -- & $12.10 \mathrm{a}$ \\
\hline & $140^{\circ} \mathrm{C}$ & $21.06 \mathrm{a}$ & -- & 3.2 & $186 b$ & -- & 11.4 & $7.73 \mathrm{~b}$ \\
\hline & $160^{\circ} \mathrm{C}$ & $18.60 \mathrm{~b}$ & 8.9 & -- & $103 c$ & 38.4 & -- & $6.40 \mathrm{c}$ \\
\hline & $180^{\circ} \mathrm{C}$ & $18.05 \mathrm{~b}$ & 14.87 & -- & $93 c$ & 44.4 & -- & $4.48 \mathrm{~d}$ \\
\hline
\end{tabular}

Note: averages followed by the same letter for the same species do not differ statistically to the level of $5 \%$ of relevance according to Tukey's test; EMC = equilibrium moisture content, \%; MOE = modulus of elasticity, MPa; MOR = modulus of rupture, MPa. 
Table 3. Parallel compression test averages of wood fibers in Eucalyptus saligna and Corymbia citriodora according to treatments.

\begin{tabular}{|c|c|c|c|c|c|c|c|c|}
\hline \multirow[b]{2}{*}{ Species } & \multirow[b]{2}{*}{ Treatments } & \multicolumn{7}{|c|}{ Parallel compression of fibers } \\
\hline & & $\begin{array}{l}\text { MOE } \\
(\mathrm{MPa})\end{array}$ & $\begin{array}{c}\text { Decrease } \\
(\%)\end{array}$ & $\begin{array}{c}\text { Increase } \\
(\%)\end{array}$ & $\begin{array}{l}\text { MOR } \\
(\mathrm{MPa})\end{array}$ & $\begin{array}{c}\text { Decrease } \\
(\%)\end{array}$ & $\begin{array}{c}\text { Increase } \\
(\%)\end{array}$ & $\begin{array}{c}\text { EMC } \\
(\%)\end{array}$ \\
\hline \multirow{4}{*}{ Eucalytus saligna } & Control & $14.22 \mathrm{a}$ & -- & -- & $67 \mathrm{a}$ & -- & -- & $12.56 \mathrm{a}$ \\
\hline & $140^{\circ} \mathrm{C}$ & $13.80 \mathrm{a}$ & 2.99 & -- & $66 \mathrm{a}$ & 1.42 & -- & $8.73 \mathrm{~b}$ \\
\hline & $160^{\circ} \mathrm{C}$ & $12.53 \mathrm{ab}$ & 11.92 & -- & $69 a$ & -- & 3.36 & $7.8 \mathrm{c}$ \\
\hline & $180^{\circ} \mathrm{C}$ & $11.83 \mathrm{~b}$ & 16.80 & -- & $60 \mathrm{~b}$ & 10.86 & -- & $6.03 \mathrm{~d}$ \\
\hline \multirow{4}{*}{ Corymbia citriodoa } & Control & $15.05 \mathrm{ab}$ & -- & -- & $83 \mathrm{a}$ & -- & -- & $12.01 \mathrm{a}$ \\
\hline & $140^{\circ} \mathrm{C}$ & $16.01 \mathrm{~b}$ & -- & 6.37 & $88 \mathrm{a}$ & -- & 6.02 & $7.83 \mathrm{~b}$ \\
\hline & $160^{\circ} \mathrm{C}$ & $15.76 \mathrm{~b}$ & -- & 4.70 & $71 \mathrm{~b}$ & 14.46 & -- & $6.74 \mathrm{c}$ \\
\hline & $180^{\circ} \mathrm{C}$ & $14.25 \mathrm{a}$ & 5.36 & -- & $68 \mathrm{~b}$ & 18.07 & -- & $6.15 \mathrm{~d}$ \\
\hline
\end{tabular}

Note: averages followed by the same letter for the same species do not differ statistically to the level of $5 \%$ of relevance according to Tukey's test; $\mathrm{EMC}=$ equilibrium moisture content, \%; $\mathrm{MOE}=$ modulus of elasticity, $\mathrm{MPa} ; \mathrm{MOR}=$ modulus of rupture, $\mathrm{MPa}$.

Table 3 illustrates parallel compression test averages of wood fibers investigated according to treatments. The statistical difference among averages in equilibrium moisture level can be observed, reducing $12 \%$ of control to almost half, approximately $6 \%$ in the treatment of $180{ }^{\circ} \mathrm{C}$ for both species.

MOE values did not differ statistically between control averages for both species. The only exception happened in the treatment of $180^{\circ} \mathrm{C}$ in E. saligna wood. This demonstrates that thermal treatment effect was not considerable in most assessments. MOE increase of $4.70 \%$ and $6.37 \%$ occurred in C. citriodora wood in relation to the control. In this same species, there was a $5.36 \%$ decrease for the treatment of $180^{\circ} \mathrm{C}$. E. saligna wood for modulus of elasticity in compression did not have any gain in relation to the control, and its greatest decrease was $16.80 \%$ in the treatment of $180^{\circ} \mathrm{C}$.

Concerning modulus of rupture for fiber parallel compression, E. saligna differed statistically only in the treatment of $180^{\circ} \mathrm{C}$. It did not differ in the other treatments. Still for this species, rupture resistance increase was $3.36 \%$ in the treatment of $160{ }^{\circ} \mathrm{C}$ and decrease of $10.86 \%$ occurred in the treatment of $180^{\circ} \mathrm{C}$.

C. citriodora wood was statistically equal to the control and the treatment of $140{ }^{\circ} \mathrm{C}$. It was different in the treatments of $160^{\circ} \mathrm{C}$ and $180^{\circ} \mathrm{C}$. For this same species, MOR increase in relation to control occurred in the treatment of $140{ }^{\circ} \mathrm{C}$ with $6.02 \%$ and its most significant loss happened in the highest temperature treatment with $18.07 \%$.
We understand that, just like in most mechanical properties' assessments, in all fiber parallel compression test values, the most expressive decreases occurred in the highest temperature treatments.

\section{CONCLUSIONS}

- As long as temperatures under $180^{\circ} \mathrm{C}$ are applied, thermorretification may be an alternative option to improve some wood mechanical properties.

- For maximum impact resistance test, Eucalyptus grandis showed higher resistance losses in both directions observed (radial and tangential). On the other hand, Corymbia citriodora had significantly milder losses. Thus, different species behave differently regarding thermorretification.

- High temperatures result in decreases in mechanical properties of both species studied. However, MOR and MOE increase in static bending was observed in lower temperatures $\left(140\right.$ e $\left.160^{\circ} \mathrm{C}\right)$.

- Parallel fiber compression in the modulus of elasticity and modulus of rupture for both species suffered a decrease in almost all treatments, with the most considerable decreases in the highest temperatures.

- For future studies, we recommend the assessment of wood chemical properties that are affected by high temperatures, mainly hemicellulose degradation.

\section{SUBMISSION STATUS}

Received: 26 sep., 2015

Accepted: 24 jan., 2018 


\section{CORRESPONDENCE TO}

\section{Maiara Talgatti}

Departamento de Ciências Florestais, Universidade Federal de Santa Maria- UFSM, Av. Roraima, 1000, Cidade Universitária, Bairro Camobi, CEP 97105-900, Santa Maria, RS, Brasil e-mail: maiara.talgatti@hotmail.com

\section{FINANCIAL SUPPORT}

The authors thank the National Council for Scientific and Technological Development (CNPQ) for research funding.

\section{REFFERENCES}

American Society for Testing and Materials - ASTM. D143 - 94: standard test methods for small clear specimens of timber. Philadelphia: ASTM; 2000. 31 p.

Araújo SO, Vital BR, Mendoza ZMSH, Vieira TA, Carneiro ACO. Propriedades de madeiras termorretificadas de Eucalyptus grandis e SP. Scientia Forestalis 2012; 40(95): 327-336.

Associação Brasileira de Normas Técnicas - ABNT. NBR 7190 - Projeto de estruturas de madeira. Rio de Janeiro: ABNT; 1997. 107 p.

Boonstra MJ, Acker J, Tjeerdsma BF, Kegel EV. Strength properties of thermally modified softwoods and its relation to polymeric structural wood constituents. Annals of Forest Science 2007; 64(7): 679-690. http://dx.doi.org/10.1051/ forest:2007048.

Calonego FW. Efeito da termorretificação nas propiedades físicas, mecânicas e na resistência a fungos deterioradores $d a$ madeira de Eucalyptus grandis Hill ex. Maiden [tese]. São Paulo: Faculdade de Ciências Agronômicas, Universidade Estadual Paulista; 2009.

Davis WH, Thompson WS. Influence of thermal treatments of short duration on the toughness and chemical composition of wood. Forest Products Journal 1964; 14(8): 350-356.
Esteves BM, Pereira HM. Wood modification by heat treatment: a review. BioResources 2004; 4(1): 370-404.

Figueroa MJM, Moraes PD. Comportamento da madeira a temperaturas elevadas. Ambiente Construído 2009; 9(4): 157-174.

Gündüz G, Korkut S, Korkut DS. The effects of heat treatment on physical and technological properties and surface roughness of Camiyani Black Pine (Pinus nigra Arn. subsp. pallasiana var. pallasiana) wood. Bioresource Technology 2008; 99(7): 2275-2280. http://dx.doi.org/10.1016/j.biortech.2007.05.015. PMid:17604619.

Modes KS. Efeito da retificação térmica nas propriedades físico-mecânicas e biológicas das madeiras de Pinus taeda e Eucalyptus grandis [dissertação]. Santa Maria: Departamento de Ciências Florestais, Universidade Federal de Santa Maria; 2010.

Moura LF, Brito JO, Bortoletto G Jr. Efeitos da termorretificação na perda de massa e propriedades mecânicas de Eucalyptus grandis e Pinus caribaea var. Hondurensis. Floresta 2012; 42(2): 305-314. http://dx.doi. org/10.5380/rf.v42i2.17635.

Rodrigues TO. Efeito da torrefação no condicionamento de biomassa para fins energéticos [dissertação]. Brasília: Universidade de Brasília; 2009.

Stamm AJ. Wood and cellulose science. New York: The Ronald Press; 1964. 549 p.

Sundqvist B, Karlsson O, Westermark U. Determination of formic-acid and acetic acid concentrations formed during hydrothermal treatment of birch wood and its relation to colour, strength and hardness. Wood Science and Technology 2006; 40(7): 549-561. http://dx.doi. org/10.1007/s00226-006-0071-z.

Winandy JE, Rowell RM. The chemistry of wood strength. In: Rowell RM. The chemistry of solid wood. Washington: American Chemical Society; 1984. p. 211-256. http:// dx.doi.org/10.1021/ba-1984-0207.ch005.

Zanuncio AJZ, Farias ES, Silveira TA. Termorretificação e colorimetria da madeira de Eucalyptus grandis. Floresta e Ambiente 2014; 21(1): 85-90. http://dx.doi.org/10.4322/ floram.2014.005. 